\title{
Experimental Study and Thermodynamic Analysis of Inclusion Precipitation during Solidification in 12\% Cr Alloy
}

\author{
Yu Hansong, Li Jianguo \\ Shanghai Jiaotong University, Shanghai 200240, China
}

\begin{abstract}
Iron based $12 \% \mathrm{Cr}$ alloy (mass fraction) is usually used for advanced electric rotors shaft which require very good mechanical property and fine inclusions, as the large-sized inclusions in the alloy can cause performance deterioration. In this work, quenching process was adopted after slow cooling experiment in order to retain the inclusions precipitated during melt cooling and solidification of $12 \% \mathrm{Cr}$ alloy. The morphology and the composition of the inclusions were detected by scanning electronic microscopy (SEM) and energy dispersive spectrometry (EDS), respectively. The results show that besides various shapes of oxide, typical TiN inclusion is found in the sample. However, there is no Ti addition in metallurgical process. Thermodynamic calculation was executed to interpret the inclusion precipitation during solidification and the calculation results indicate that TiN inclusion precipitates at the terminal stage of solidification. Even a trace amount of Ti drawn from raw materials would induce the precipitation of TiN, which would grow into large size and be harmful to alloy property, while the formation of $\mathrm{Al}_{2} \mathrm{O}_{3}$ inclusion occurs in liquid alloy. Suggestions for the control of Ti and $\mathrm{O}$ are given based on the calculation results, which would be helpful to the production of $12 \% \mathrm{Cr}$ alloy. The precipitation potential of $\mathrm{Ti}_{2} \mathrm{O}_{3}$ inclusion in the experiment has also been discussed by studying the competition of element concentration between $\mathrm{Ti}$ and $\mathrm{Al}$.
\end{abstract}

Key words: inclusion precipitation; solidification; $12 \% \mathrm{Cr}$ alloy; thermodynamic calculation

$12 \% \mathrm{Cr}$ alloy is used for manufacturing advanced electric rotor shafts which work under severe working condition (high temperature, steam corrosion, energy radiation, etc.) and require excellent performances on high-temperature strength, creep resistance, impact behavior, and so on ${ }^{[1]}$. Since inclusions reserved in the product have significant effect on properties and can cause kinds of problems such as strength weakening, fatigue failure, impaction degradation, and so forth $^{[2]}$, it is worthwhile to pay attention to the formation of inclusions in $12 \% \mathrm{Cr}$ alloy, especially the inclusions formed during solidification, as inclusions which appear and grow up in this period are maintained in the final industrial production, not like primary inclusions which are mainly wiped out.

Many previous studies have been carried out to investigate inclusions during solidification by combining with thermodynamic analysis via kinds of materials ${ }^{[3-5]}$. However, there is few discussion about the formation of inclusions during solidification for $12 \% \mathrm{Cr}$ alloy. Research works related to $12 \% \mathrm{Cr}$ alloy mainly focused on the microstructure evolution ${ }^{[6,7]}$, or carbonitrides precipitation like $\mathrm{M} X(\mathrm{M}=$ metal, $X=\mathrm{C}, \mathrm{N})$ and Cr-based carbides $\left(\mathrm{Cr}_{23} \mathrm{C}_{6}, \mathrm{Cr}_{7} \mathrm{C}_{3}\right)$ during heat treatment process ${ }^{[8,9]}$. But the control for inclusion is also one of the fundamental requirements in the production considering its industrial applicability. Therefore, more interest should be paid to the inclusion formation in $12 \% \mathrm{Cr}$ alloy.

In the present study, a special procedure quenching was initiated after slow cooling experiment to reserve the inclusions formed during solidification in $12 \% \mathrm{Cr}$ alloy, because inclusions observed in conventional solidification process can be controversial on whether they precipitate during melt cooling and solidification, or even in solid phase cooling period. The morphology and composition of inclusions were identified by SEM and EDS, respectively.

Received date: May 25, 2016

Foundation item: National Key Basic Research Development Program of China ("973" Program) (2011CB012900)

Corresponding author: Li Jianguo, Professor, School of Materials Science and Engineering, Shanghai Jiaotong University, Shanghai 200240, P. R. China, Tel 0086-21-54744119, E-mail: lijg@sjtu.edu.cn

Copyright (C) 2017, Northwest Institute for Nonferrous Metal Research. Published by Elsevier BV. All rights reserved. 
Meanwhile, thermodynamic calculation was employed on types of inclusions which were displayed in the experiment so as to understand their formation. Based on thermodynamics a few suggestions for the composition controlling are given in order to improve the manufacture of $12 \% \mathrm{Cr}$ alloy.

\section{Experiment Procedure}

The raw $12 \% \mathrm{Cr}$ alloy with dimension of $75 \mathrm{~mm}$ in length and $25 \mathrm{~mm}$ in diameter was prepared. Then it was put into a high purity quartz crucible and placed in an induction furnace which was filled with argon atmosphere to $0.05 \mathrm{~Pa}$ gas pressure after evacuating by a mechanical pump and a molecular pump. The alloy was heated to $1873 \mathrm{~K}$ and held for $5 \mathrm{~min}$ in order to stabilize the melt. Subsequently it was cooled down at a cooling rate of $0.05 \mathrm{~K} / \mathrm{s}$ by gradually turning down the power. Under such a slow cooling rate, the formation of non-metallic inclusion could be regarded in a quasi-equilibrium state. Finally when the temperature reached $1688 \mathrm{~K}$, the solidus temperature of $12 \% \mathrm{Cr}$ alloy, which was calculated by the software JMat-Pro, the sample was quenched in water to suppress the precipitation after solidification, so the inclusions which had formed from melt cooling and solidification were reserved. In the experiment, all the temperatures were recorded by an infrared temperature measurement system.

The chemical composition of experimental alloy is shown in Table 1. The content of carbon and sulfide were analyzed by carbon and sulfur analyzer while oxygen and nitrogen contents were analyzed via inert gas fusion-infrared absorptiometry. The component of other metallic elements such as $\mathrm{Cr}, \mathrm{Al}$, and $\mathrm{Ti}$ were analyzed by an inductively coupled plasma-atomic emission spectrometry (ICP). Though no titanium was added during metallurgical process, a trace amount of titanium were detected in the alloy. It is speculated that such few titanium drawn from scrap iron were the primary charge of raw material.
In order to observe the morphology and detect the composition of inclusions reserved in the alloy, preparation was as follows: firstly, the sample was cross-section cut, mechanically ground with silicon carbide emery paper down to 2000 grit, and then polished with diamond pastes down to $1 \mu \mathrm{m}$; subsequently it was ultrasonically rinsed in distilled water. After all these above, the examination on the sample was executed via a scanning electron microscopy (SEM, Jeol JSM-7600F) equipped with an energy dispersive spectrometry (EDS).

\section{Results and Discussion}

\subsection{Precipitation of TiN inclusion in the experiment}

Experimental results in Fig. 1 show the morphology of TiN inclusion, which has a typical rectangular shape reported in references ${ }^{[10,11]}$. The size of TiN observed is about $2 \sim 3 \mu \mathrm{m}$ and Fig.1b gives a clear magnification of it. EDS detection shows that the inclusion content (mass fraction) is: $\mathrm{Ti} 32.42 \%, \mathrm{~N}$ $18.88 \%$, Fe $42.97 \%$ and $\mathrm{Cr} 5.73 \%$, where $\mathrm{Fe}$ and $\mathrm{Cr}$ comes from the base material.

Thermodynamics of $\mathrm{TiN}$ in the alloy was calculated. Titanium has very strong affinity with nitrogen, and the reaction between $\mathrm{Ti}$ and $\mathrm{N}$ can be expressed by Eq. (1) ${ }^{[12]}$ :

$$
\begin{aligned}
& \mathrm{Ti}+\mathrm{N}=\mathrm{TiN} \\
& \lg \frac{\alpha_{\mathrm{TiN}}}{\alpha_{\mathrm{Ti}} \cdot \alpha_{\mathrm{N}}}=\lg \frac{1}{f_{\mathrm{Ti}}[\% \mathrm{Ti}] f_{\mathrm{N}}[\% \mathrm{~N}]}=17040 / T-6.40
\end{aligned}
$$

where $\alpha_{\mathrm{Ti}}, \alpha_{\mathrm{N}}$ are the activities of element $\mathrm{Ti}$ and $\mathrm{N}$, respectively, and $\alpha_{\text {TiN }}$ is considered as 1 due to its low solubility. In the present study the activity of inclusion is unity (pure inclusion as the standard state). [\% Ti], [\%N] are the weight percentage of elements $\mathrm{Ti}$ and $\mathrm{N}$, respectively. $f_{\mathrm{Ti}}, f_{\mathrm{N}}$ are the elements activity coefficients which are determined by Wagner's formalism described in Eq. (2).

$$
\lg f_{i}=\sum \mathrm{e}_{i}^{j}[\% j]
$$

where $\mathrm{e}_{j}^{i}$ is the first-order interaction parameters of element $j$ to $i$, and [\%j] is mass percent of element $j$. Their values are

Table 1 Chemical composition of $12 \%$ Cr alloy (wt\%)

\begin{tabular}{ccccccccccc}
\hline $\mathrm{C}$ & $\mathrm{Si}$ & $\mathrm{Mn}$ & $\mathrm{P}$ & $\mathrm{S}$ & $\mathrm{Cr}$ & $\mathrm{Al}$ & $\mathrm{Ti}$ & $\mathrm{O}$ & $\mathrm{N}$ \\
\hline 0.12 & 0.11 & 0.43 & 0.01 & 0.0086 & 10.53 & 0.01 & 0.005 & 0.005 & 0.054 \\
\hline
\end{tabular}

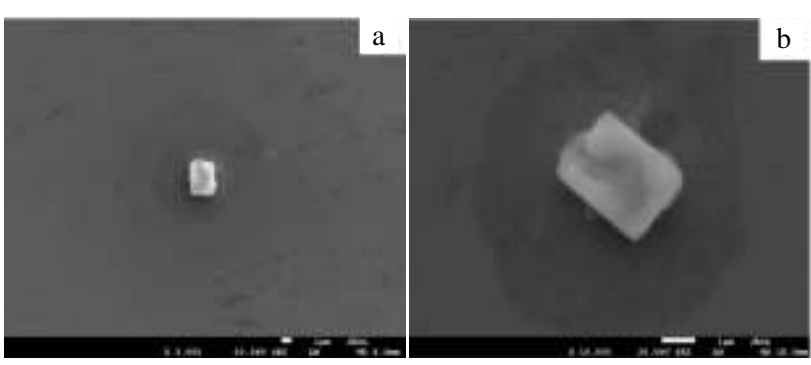

Fig. 1 Typical TiN inclusion observed in the sample obtained from literatures available and listed in Table 2. The liquidus temperature and solidus temperature of $12 \% \mathrm{Cr}$ alloy are calculated to be $1773 \mathrm{~K}$ and $1688 \mathrm{~K}$ by the software JMat-Pro, respectively.

Fig. 2 shows the stability diagram of TiN precipitation during solidification for $12 \% \mathrm{Cr}$ alloy. The curves were calculated according to Eq.(1) and lever rule which was used to describe solutes segregation during solidification in equilibrium state. Before calculation it was assumed that $\mathrm{Ti}$ consumption occurred only if TiN precipitation took place. The black point in Fig.2 represents the actual concentration of 


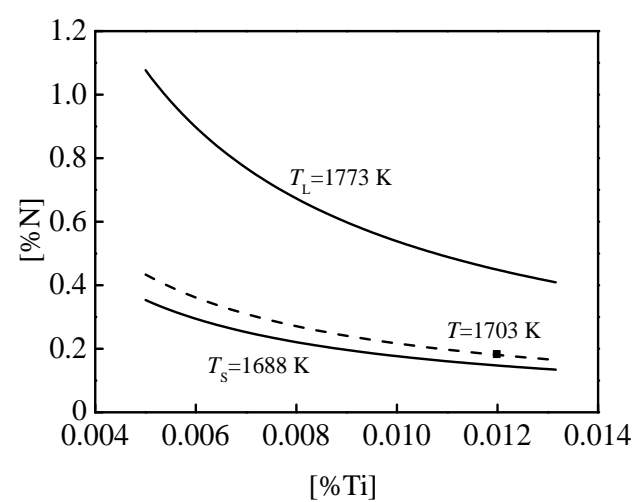

Fig.2 Stability diagram of TiN precipitation during solidification

titanium and nitrogen caused by segregation and the dashed line across the point corresponds to the solutes equilibrium at $1703 \mathrm{~K}$, at which TiN start to appear. It can be seen that $\mathrm{TiN}$ is formed at a temperature much lower than the liquidus temperature and very close to the solidus temperature. As $12 \%$ $\mathrm{Cr}$ alloy is not deoxidized by $\mathrm{Ti}$, the $\mathrm{Ti}$ it contained is all from raw materials for metallurgical process. It is obvious that $0.005 \%$ of $\mathrm{Ti}$ can cause the formation of TiN during solidification because of double factors: high content of $\mathrm{N}$ and solutes segregation. TiN formed during solidification grows to a size of $2 \sim 3 \mu \mathrm{m}$ under slow cooling rate and such large-sized TiN could weaken the mechanical properties ${ }^{[11]}$. As in industry manufacture, $\mathrm{Ti}$ has not been added in for deoxidation, its content control has not attracted much attention. It is supposed that if no TiN precipitation happened during the whole solidification period, Ti content should be less than $0.003 \%$, which was calculated by the content of $\mathrm{Ti}$ and $\mathrm{N}$ in Table 1 and equilibrium described in Eq. (1).

\subsection{Formation of $\mathrm{Al}_{2} \mathrm{O}_{3}$ inclusion in the experiment}

Fig. 3 shows the typical oxide inclusions with various sizes and shapes in the experiment. As demonstrated in Fig.3a, a large size inclusion (approximately $8 \mu \mathrm{m}$ ) with rugged surface may be formatted in the melt, or aggregated by several small inclusions during solidification. The component identified by EDS lists in mass fraction is as follows: $\mathrm{Al} 45.36 \%$, O $44.27 \%$, $\mathrm{Fe} 9.14 \%$ and $\mathrm{Cr} 1.23 \%$. It reveals that alumina can grow into large size inclusion in $12 \% \mathrm{Cr}$ alloy. Inclusions with $2 \sim 3 \mu \mathrm{m}$ sizes are distributed in Fig.3b and 3c, spherical inclusion in Fig. $2 b$ has a very smooth surface with adhesion which implies that inclusion formed previously could be the substrate for other inclusions deposited on. Single irregular inclusion with no attachment also can be seen in Fig.3c. Since their sizes are much smaller, they are assumed to be formed during solidification. In both Fig. 3c and 3d, fine inclusion with sizes close to $1 \mu \mathrm{m}$ or even less appears, which are speculated to precipitate at the terminal stage of solidification.

The equilibrium deoxidation reaction caused by $\mathrm{Al}$ is established as Eq. (3) ${ }^{[13]}$ :

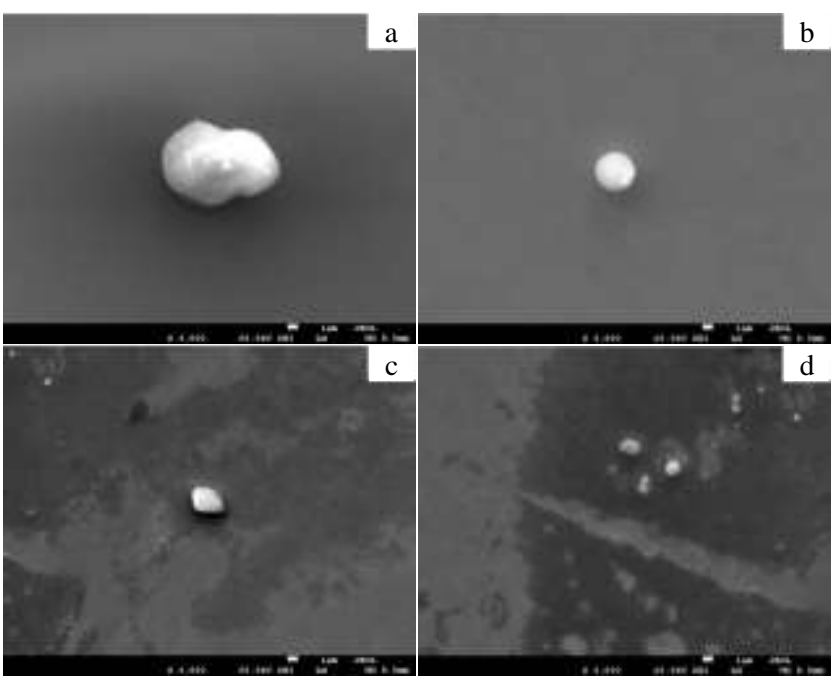

Fig.3 Typical oxide inclusions observed in the sample: (a) alumina inclusion with large size, (b) spherical and smoothed-surface inclusion with adhesion, (c) single irregular inclusion, and (d) fine inclusions with sizes close to $1 \mu \mathrm{m}$

$$
\begin{aligned}
& 2 \mathrm{Al}+3 \mathrm{O}=\mathrm{Al}_{2} \mathrm{O}_{3} \\
& \lg \left(\frac{\alpha_{\mathrm{Al}_{2} \mathrm{O}_{3}}}{\alpha_{\mathrm{Al}}^{2} \cdot \alpha_{\mathrm{O}}^{3}}\right)=\lg \left(\frac{1}{f_{\mathrm{Al}}^{2} \cdot[\% \mathrm{Al}]^{2} \cdot f_{\mathrm{O}}^{3} \cdot[\% \mathrm{O}]^{3}}\right)=45300 / T-11.62
\end{aligned}
$$

where $\alpha_{\mathrm{Al}}, \alpha_{\mathrm{O}}$ are the activities of element $\mathrm{Al}$ and $\mathrm{O}$, respectively, and $\alpha_{\mathrm{Al}_{2} \mathrm{O}_{3}}$ is considered to be 1. [\% Al], [\% $\mathrm{O}$ ] are the mass percentage of elements of $\mathrm{Al}$ and $\mathrm{O}, f_{\mathrm{Ti}}, f_{\mathrm{O}}$ are the activity coefficients of $\mathrm{Ti}$ and $\mathrm{O}$, respectively.

Fig.4 shows the stability diagram of $\mathrm{Al}_{2} \mathrm{O}_{3}$ formation in the melt of $12 \% \mathrm{Cr}$ alloy. The curves were calculated according to Eq. (3). The black point in Fig.4 represents the actual concentration of aluminum and oxygen. From the figure it could be seen that $\mathrm{Al}_{2} \mathrm{O}_{3}$ existed in the melt at $1873 \mathrm{~K}$ because of the strong solutes oversaturation. It is assumed that if $\mathrm{Al}_{2} \mathrm{O}_{3}$ precipitate not until melt solidification, by the calculation result from element content in Table 1 and equilibrium presented in Eq.(3), oxygen content should be less than $16 \mu \mathrm{g} / \mathrm{g}$.

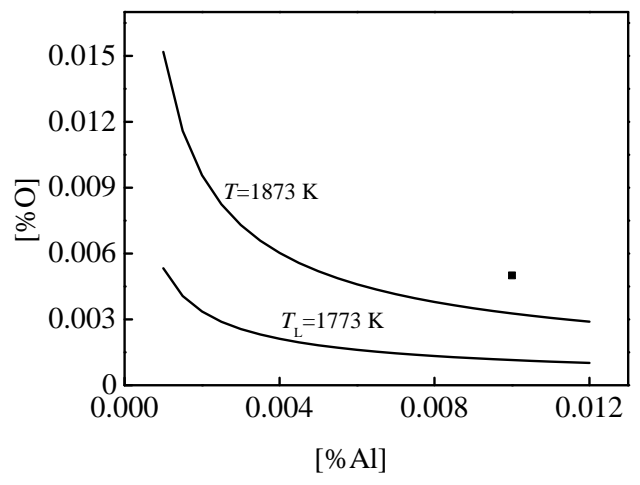

Fig.4 Stability diagram of $\mathrm{Al}_{2} \mathrm{O}_{3}$ formation in liquid alloy 
Table 2 Interaction coefficients of components used in the study

\begin{tabular}{ccccccccccc}
\hline $\mathrm{e}_{j}^{i}$ & $\mathrm{C}$ & $\mathrm{Si}$ & $\mathrm{Mn}$ & $\mathrm{P}$ & $\mathrm{S}$ & $\mathrm{Cr}$ & $\mathrm{Al}$ & $\mathrm{Ti}$ & $\mathrm{O}$ & $\mathrm{N}$ \\
\hline $\mathrm{Ti}$ & 0.19 & -0.025 & $-0.043^{[13]}$ & - & -0.27 & $-0.016^{[14]}$ & 0.93 & $0.042^{[13]}$ & -3.4 & -2.04 \\
$\mathrm{~N}$ & 0.13 & 0.047 & -0.02 & 0.045 & 0.007 & -0.043 & -0.028 & -0.59 & 0.05 & -0.028 \\
$\mathrm{Al}$ & 0.091 & 0.03 & 0.035 & 0.033 & 0.035 & $0.012^{[15]}$ & 0.043 & 0.004 & -1.98 & -0.058 \\
$\mathrm{O}$ & -0.421 & -0.066 & $-0.037^{[16]}$ & 0.07 & -0.133 & -0.032 & -1.17 & -1.12 & -0.174 & 0.057 \\
\hline
\end{tabular}

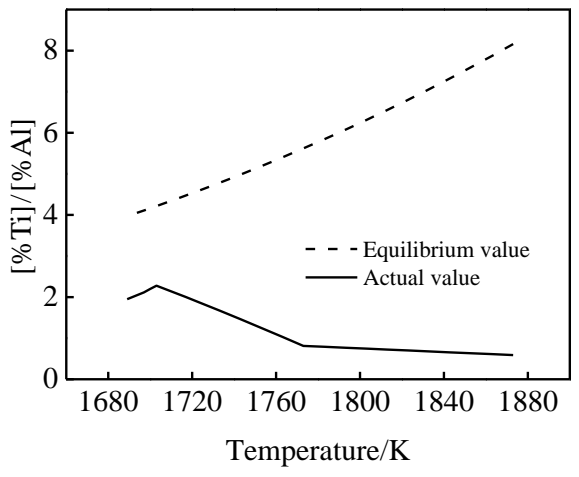

Fig.5 Concentration ratio of $\mathrm{Ti}$ and $\mathrm{Al}$ for $\mathrm{Ti}_{2} \mathrm{O}_{3}$ precipitation during cooling and solidification

\subsection{Precipitation potential of $\mathrm{Ti}_{2} \mathrm{O}_{3}$ inclusion}

Though Al content is at higher level than Ti content, deoxidation reaction caused by $\mathrm{Ti}$ may occur when $\mathrm{Al}$ is consumed to an extent and $\mathrm{Ti}_{2} \mathrm{O}_{3}$ is considered to be a kind of probable deoxidation product ${ }^{[17]}$. The reaction equilibrium between $\mathrm{Ti}$ and $\mathrm{O}$ is described as Eq.(4) ${ }^{[18]}$ :

$$
\begin{aligned}
& 2 \mathrm{Ti}+3 \mathrm{O}=\mathrm{Ti}_{2} \mathrm{O}_{3} \\
& \lg \left(\frac{\alpha_{\mathrm{Ti}_{2} \mathrm{O}_{3}}}{\alpha_{\mathrm{Ti}}^{2} \cdot \alpha_{\mathrm{O}}^{3}}\right)=\lg \left(\frac{1}{f_{\mathrm{Ti}}^{2} \cdot[\% \mathrm{Ti}]^{2} \cdot f_{\mathrm{O}}^{3}[\% \mathrm{O}]^{3}}\right)=56060 / T-18.08
\end{aligned}
$$

Eq. (4) subtracts Eq. (3):

$$
\begin{aligned}
& 2 \mathrm{Ti}+\mathrm{Al}_{2} \mathrm{O}_{3}=2 \mathrm{Al}+\mathrm{Ti}_{2} \mathrm{O}_{3} \\
& \lg \left(\frac{\alpha_{\mathrm{Ti}_{2} \mathrm{O}_{3}} \cdot \alpha_{\mathrm{Al}}^{2}}{\alpha_{\mathrm{Al}_{2} \mathrm{O}_{3}} \cdot \alpha_{\mathrm{Ti}}^{2}}\right)=\lg \left(\frac{\alpha_{\mathrm{Al}}^{2}}{\alpha_{\mathrm{Ti}}^{2}}\right)=10760 / T-6.46
\end{aligned}
$$

Based on Eq.(2) and Eq. (5), combing with the chemical composition listed in Table 1 and the interaction coefficients given in Table 2, the equilibrium relationship between the concentration of $\mathrm{Ti}$ and $\mathrm{Al}$ can be calculated as:

$[\% \mathrm{Ti}] /[\% \mathrm{Al}]=10^{(3.784-5380 / T)}$

Fig. 5 shows the precipitation potential of $\mathrm{Ti}_{2} \mathrm{O}_{3}$ during the melt cooling and solidification process. At the stage of melt cooling, the ratio of $[\% \mathrm{Ti}] /[\% \mathrm{Al}]$ keeps increasing with the decreasing temperature due to the precipitation of $\mathrm{Al}_{2} \mathrm{O}_{3}$, then the concentration ratio is accelerated because of the microsegregation during solidification and reaches its maximum value until the precipitation of TiN. But in the whole temperature range from $1873 \mathrm{~K}$ to $1688 \mathrm{~K}$, the actual value of concentration ratio is always less than the equilibrium value. It is predicted that no $\mathrm{Ti}_{2} \mathrm{O}_{3}$ could precipitate in the experiment, and there is no $\mathrm{Ti}_{2} \mathrm{O}_{3}$ observed in the sample.

\section{Conclusions}

1) Quenching after slow cooling experiment was carried out to investigate the inclusion precipitation in $12 \% \mathrm{Cr}$ alloy during solidification, $\mathrm{TiN}$ and $\mathrm{Al}_{2} \mathrm{O}_{3}$ inclusions are found and the results of thermodynamic calculation are in good agreement with the experiment.

2) Typical TiN inclusion precipitates at the terminal stage of solidification based on the calculation results and only a trace amount of $\mathrm{Ti}$ from scrap iron could induce the precipitation of TiN. It is suggested that Ti content less than $0.003 \%$ could suppress the precipitation of TiN during solidification.

3) $\mathrm{Al}_{2} \mathrm{O}_{3}$ inclusions can exist in liquid alloy and if $\mathrm{Al}_{2} \mathrm{O}_{3}$ is not expected to format until solidification, oxygen content should be less than $16 \mu \mathrm{g} / \mathrm{g}$. No $\mathrm{Ti}_{2} \mathrm{O}_{3}$ could precipitate in the melt though the concentration of $\mathrm{Ti}$ increases during cooling and solidification.

\section{References}

1 Masuyama F. ISIJ International[J], 2001, 41: 612

2 Jung I H, Decterov S A, Pelton A D. ISIJ International[J], 2004, 44: 527

3 Wang Y, Valdez M, Sridhar S. Metallurgical and Materials Transactions $B[\mathrm{~J}], 2002$, 33: 625

4 Nurmi S, Louhenkilpi S, Holappa L. Steel Research International[J], 2009, 80: 436

5 Zhuo X J, Wang X H, Wang W J et al. Journal of University of Science and Technology Beijing[J], 2007, 14: 14

6 Pryds N H, Johnson E, Linderoth S et al. Metallurgical and Materials Transaction A[J], 1998, 29: 367

7 Song C J, Guo Y Y, Li K F et al. Metallurgical and Materials Transactions $B[\mathrm{~J}], 2012,43: 1127$

8 Janovec J, Svoboda M, Blach J. Materials Science and Engineering $A[\mathrm{~J}], 1998,249: 184$

9 Prat O, Garcia J, Rojas D et al. Materials Science and Engineering A[J], 2010 527: 5976

10 Pak J J, Jeong Y S, Hong I K et al. ISIJ International[J], 2005, 45: 1106

11 Ma W J, Bao Y P, Zhao L H et al. International Journal of Minerals, Metallurgy, and Materials[J], 2014, 21: 234

12 Wang M L, Cheng G G, Zhao P. Journal of Iron and Steel Research [J], 2004, 16: 40 (in Chinese)

13 Park J H, Lee S B, Gaye H R. Metallurgical and Materials 
Transaction $B[\mathrm{~J}], 2008,39: 853$

14

Hong Z, Wu X C, Kun C. Steel Research[J], 1995, 66: 72

Takahashi K, Hino M. High Temperature Materials and
Processes[J], 2000, 19: 1

17 Shim J H, Cho Y W, Chung S H et al. Acta Materialia[J], 1999 47: 2751

18 Ma Z T, Janke D. ISIJ International[J], 1998, 38: 46

\title{
$12 \% \mathrm{Cr}$ 合金凝固过程夹杂物析出的实验研究与热力学分析
}

\author{
余汉松，李建国 \\ (上海交通大学，上海 200240)
}

\begin{abstract}
摘 要: 铁基 $12 \% \mathrm{Cr}$ 合金（质量分数）常被用来制造先进电机转子。电机转子要求材料具备良好的机械性能和细小的夹杂物，大尺寸的 夹杂物通常会使得其性能恶化。本研究在缓冷试验后采用淬火工艺, 保留了 $12 \% \mathrm{Cr}$ 合金液态冷却和凝固过程中形成的夹杂物, 并通过扫 描电子显微镜和能谱分析对夹杂物的形貌及化学成分进行了分析。结果表明: 除各种氧化物夹杂外, 在试样中观察到典型的氮化钛夹杂, 但冶炼过程中并未添加钛元素。夹杂物析出的热力学计算结果表明: 氮化钛夹杂析出于凝固末期, 来自原料中痕量的钛元素即可导致氮 化钛的析出，而氧化铝夹杂在液态合金中即可生成。通过控制钛元素和氧元素的含量在合理范围，有利于抑制凝固过程的夹杂析出。同 时对凝固过程三氧化二钛夹杂析出的可能性进行了研究。
\end{abstract}

关键词: 夹杂物析出; 凝固; $12 \% \mathrm{Cr}$ 合金; 热力学计算

作者简介: 余汉松, 男, 1982 年生, 博士, 上海交通大学材料科学与工程学院, 上海 200240, 电话: 021-54744119, E-mail: yuhansong@sjtu.edu.cn 